\title{
The Absolute Isotopic Abundance and Atomic Weight of a Reference Sample of Silver
}

\author{
L. J. Powell, ${ }^{\star} \dagger$ T. J. Murphy, ${ }^{*}$ and J. W. Gramlich* \\ National Bureau of Standards, Washington, DC 20234
}

\begin{abstract}
August 12, 1981
The atomic weight of a referenee sample of silver has been determined by mass speetrometry, with an uncertairty of one part in $10^{\circ}$, using a single filament silica gel proeedure. Accurately kuown quantities of chemically pure ${ }^{107} \mathrm{Ag}$ and ${ }^{109} \mathrm{Ag}$ were mixed to produce standards of known isotopic composition for calibration of the mass spectrometer. The absolute isolopic ratio of the refcrence sample of silver is ${ }^{107} \mathrm{Ag} /{ }^{109} \mathrm{Ag}=1.07638$ \pm 0.00022 yielding an atomic weight of $107.86815 \pm 0.00011$. The indicaled unccrtainties represent an overall limit of error at the 95 percent confidence levcl which is the sum of the uncertainty components for the ratio determined and the components covering effects of known sources of possible systematic error.
\end{abstract}

Key words: Absolute ratios: atomic weighı; Faraday Constant; isotopic abundance; mass spectrometry; silica gel; silver; silver iodide.

\section{Introduction}

The inorganic mass spectrometry group of the National Bureau of Standards has been conducting a long term program of absolute isotopic abundance ratio and atomic weight determinations using high precision isotope ratio mass spectrometry. Previous atomic weight determinations include silver [1], ${ }^{1}$ chlorine [2], eopper [3], bromine [4], chromium [5], magnesium [6], lead [7], boron [8], rubidium [9], rhenium [10], silicon [11], potassium [12], thallium [13], and strontium [14].

The present work, a redetermination of the atomic weight of silver, was undertaken in conjunction with the calculation of a more accurate Faraday constant. The Faraday is directly related to other physical constants including the Avogadro constant, the proton gyromagnetic ratio, the magnetic moment of the proton in uuelear magnctons, and the ratio of the NBS as-maintained ampere to the absolute or SI ampere. Over the years a problem arose iu assigning a reeommended value for the Faraday due to apparent diserepancies between the Faraday determined from electrochemical experiments and the Faraday calculated from other fundamental constants. Unfortunately, earlier electrochemical experiments were not suffieiently precise $(6.8 \mathrm{ppm}$, one standard deviation, for the best silver determination) to either prove or disprove the existenee of this discrepancy. As a result, the Faraday was exeluded from the most recent (1973) least squares adjustment of the fundamental constants [28].

\footnotetext{
- Cenler for Analytical Chemistry, Natioual Measurement Laboratory.

† Previous publicalions of this author have been under the name of $L$. P. Dunstan.

I Figures in brackels indicate litcrature references al the end of this paper.
}

In 1980, Bower and Davis [15], using the same source of silver as was analyzed in this work, NBS Standard Reference Material (SRM) 748, published a new value for the electrochemical equivalent of silver with an accuracy of $1.28 \mathrm{ppm}$ (one standard deviation). The ealculation of the Faraday using this value and the 1962 atomic weight of silver [1], indicaled that significant differenees between the various Faraday calculations might indeed exist. In order to assess the significance of these differences, however, it became necessary to significantly reduce the uncertainty in the atomic weight of silver.

The method used for the determination of atomic weights at NBS, which has been briefly described in previous publications [1-14], and may be described as calibrated mass spectromctry, combines the techniques of high precision chemical assay with high precision mass spectrometry. The mass spectrometers to be used for the isotopie abundance measurements are calibrated for bias using synthetic mixes of known isotopic composition, prepared from nearly pure separated isotopes. Extensive rcseareh has demonstrated that this bias is due to non-linearities in the measurement cireuit and mass-dependent isotopic fractionation [16]. In the case of ratios near one, this bias rcduces to isotopie fractionation. These measured biases are then used to caleulate the absolute isotopie abundance ratio and, ultimately, the alomic weight of the reference sample. A bloek diagram characterizing the atomic weight method is shown in figure 1 .

The chemical researeh requires the development of an assay procedure for the pure element or reference sample preeise to at least one part in $10^{4}$, which will ultimately be used to assay the separated isotope solutions. In addition, a 
Mass Spectrometric Atomic Weight Method

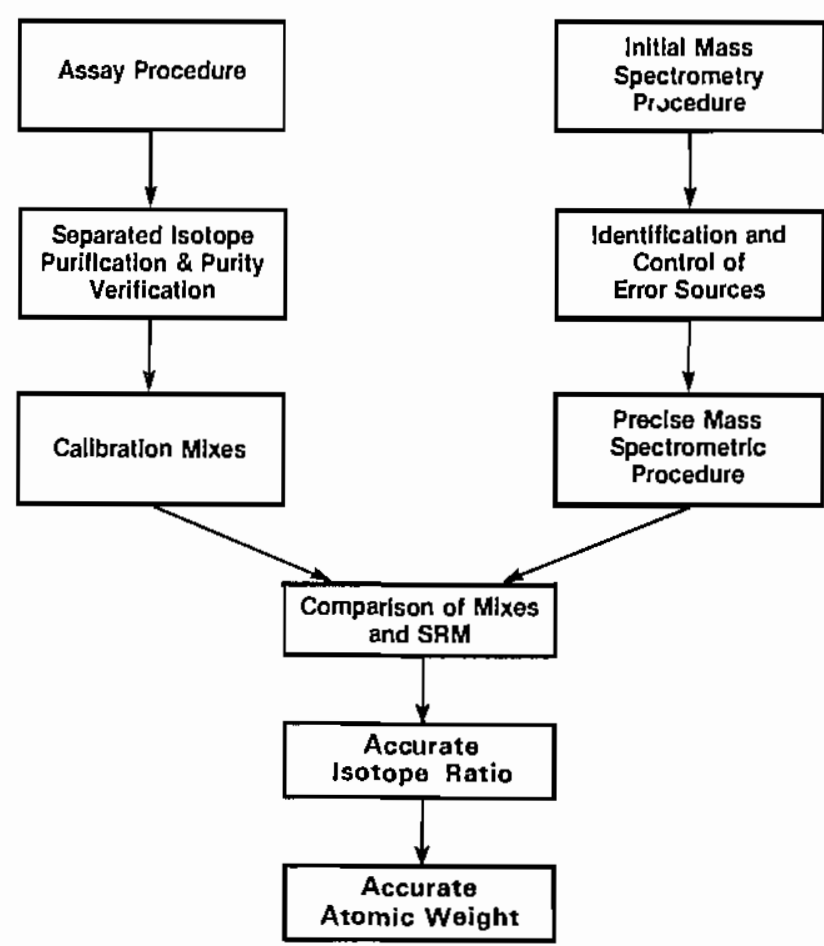

Figure 1.

proeedure must be developed to purify the separated isotopes to eliminate impurities which could interfere with either the chemical or mass spectrometric procedures. Once these methods have been thoroughly lested using the reference sample, the separated isotopes are purified and dissolved. Aliquots of each isotope are then taken to produce calibration mixes which are blended to braeket the natural isotopic abundance ratio of the element. In addition, aliquots of each isotope are taken for assay so that accurate solution concentrations can be ascertained. A knowledge of the solution concentrations combined with aliquoting data allows the actual ratios of the calibration mixes to be calculated.

The mass spectrometric research involves the development of a high precision method for the analysis of the relative isotopic abundance ratios of the reference sample, followed by a comprehensive study to identify and control any sources of bias which conld affect the final measurements.

After the above tasks have been accomplished, two complete sets of analyses of the calibration mixes and the SRM are made by two different operators using differcnt mass spectrometers. The calibration mixes are randomly selected and are analyzed in an alternating pattern with the referencc sample. A comparison of the relative isotopic abundance ratios obtained for the calibration mixes with the calculated or true value produces a calibration factor. This factor is applied to the relative isotopic ratio obtaincd for the SRM to produce the absolute isotopic abundance ratio. The atomic weight is then obtained by multiplying the fractional abundance of each isotope by its nuclidic mass ${ }^{2}$ and summing the resultant products.

\section{Experimental Procedure ${ }^{3}$}

\subsection{Mass Spectrometry}

The isotopic ratio measurements were made using two nearly identical $90^{\circ}, 30 \mathrm{~cm}$ radius of curvature solid sample mass spectrometers equipped with a " $Z$ " lens focusing source [18]. The collector was a deep bucket $F$ araday cup equipped with a 50 percent transmission grid shadowing a series of suppression grids [18-20]. The measuring eireuit consisted of two vibrating reed electrometers (VRE) and a voltage-to-frequency conversion system which transmits data to a eomputer for data acquisition. Prior to initiating the alomic weight ratio determinations, the measuring circuits of the mass spectromelers were calibrated and found to be linear to within one part in $10^{4}$ over a range of $30-80$ percent of full seale for each VRE scale. However, the linearity of the measurement eleetronies becomes insignificant because of the equal atom composition of the standard and most of the mixes. Under these conditions any non-linearities in the ralio measurement will eancel, and any possible effects would be indicated by the endpoint ealibration mixes.

The relative isotopic composition of the calibration mixes and the reference sample were determined by surface ionization mass spectrometry using a platinum single fit.ument silica gel technique.

The filaments used in this work were fabricated from 99.9 percent pure platinum ribbon $(0.025 \times 0.76 \mathrm{~mm})$ and were cleaned by heating at $2.5 \mathrm{~A}$ for $1 \mathrm{~h}(\mathrm{r})$ in a vacuum and under a potential field.

The sample mounting was carried out in two stages, hereafter referred to as the low tcmperature drying stage and the high temperalure drying stage. The low temperature drying stage was similar to the lead-silica gel method described by Barnes et al., [21]. A $5 \mu \mathrm{L}$ drop of silica gel suspension was placed on the filament surface and dried at $1.0 \mathrm{~A}$ for $5 \mathrm{~min}$. A second drop of silica gel was added and the drying repeated. A $5 \mu \mathrm{L}$ drop of silver as $\mathrm{AgNO}_{3}$ in $(1+9)^{4} \mathrm{HNO}_{3}$ was placed

\footnotetext{
2 Nuclidic masses, as published in Wapstra and Bos [17] are known to parts per billion accuracies.

In order to describe adequatcly materials, instruments, equipıneul, anul procedures. it was occasionally necessary to identify commercial products by mantuacturer's name or label. In no instance does such identification isply endorsement by the National Bureau of Standarls nor does it inply that the partienlar procluct or expipment is necessarily the best available for thal purpose.

- A reagent dilution of $(1+9)$ indicates 1 volume of concentrated reogent diluted with 9 volumes of pure water. If no dilution is specified. use of the concentraled reagent is implied. The acids and water used for these dilulions were produed at NBS by subboiling distillation [23].
} 
on top of the siliea gel and dried at $1.0 \mathrm{~A}$ for $5 \mathrm{~min}$. A drop of $0.75 \mathrm{~N} \mathrm{H}_{3} \mathrm{PO}_{4}$ was then added and dried at $1.5 \mathrm{~A}$ for 5 min then at $2.0 \mathrm{~A}$ for $5 \mathrm{~min}$. This drying proeedure was carried out in a elass 100 clean air hood with an airllow of 100 linear $\mathrm{ft} / \mathrm{s}$ per $\mathrm{s}$ using a programmable sample drier designed by Gramlich and Shideler [22]. Throughout the procedure a heat lamp, whose intensity was adjusted to yicld a temperature of $70{ }^{\circ} \mathrm{C}$ at the filament surface, was uscd to aid the drying proeess.

The high temperature drying stage was accomplished using pyrometer adjustment of the filament temperature. This method was first used for the determination of the atomic weight of thallium [13] and has since proved to be an important key to controlling the reproducibility of isotopic ratios of a number of elements. The filament was covered with a bell jar and purged with nitrogen gas for $5 \mathrm{~min}$. The nitrogen flow was stopped and the filament was adjusted to a temperature of $1040{ }^{\circ} \mathrm{C}$ for $60 \mathrm{~s}$.

After loading the sample into the source of the mass speetrometer, the system was allowed to pump down to a pressure of at least $2 \times 10^{-6}$ torr $(300 \mu \mathrm{Pa})$ before starting the analysis. Liquid nitrogen was then added to the source cold finger to reduce the pressure to less than $1 \times 10^{-7}$ torr ( 10 $\mu \mathrm{Pa})$. At $t=0 \mathrm{~min}$, the temperature of the filament was increased to $760^{\circ} \mathrm{C}$. This yielded a ${ }^{107} \mathrm{Ag}$ ion beam intensity $1-2 \times 10^{-12}$ A. At $t=25 \mathrm{~min}$, the temperature of the filament was increased to $790{ }^{\circ} \mathrm{C}$. At this temperature the intensity of the ${ }^{107} \mathrm{Ag}$ ion beam was between $5 \times 10^{-12} \mathrm{~A}$ and $1 \times 10^{-11} \mathrm{~A}$. If the intensity of the ${ }^{107} \mathrm{Ag}$ ion beam was outside of these limits, the analysis was rejected. Baseliue data were taken and ratio data were collected between $t=$ 30 and $50 \mathrm{~min}$.

\subsection{Purification of Separated Silver Samples}

Eleetromagnetically separated ${ }^{107} \mathrm{Ag}$ and ${ }^{109} \mathrm{Ag}$ isotopes in the form of silver metal powder were obtained from the Nuclear Division, Oak Ridge National Laboratory of the Union Carbide Nuclear Company. The ${ }^{107} \mathrm{Ag}$ was designated series $R \& D$, sample 000101 and the ${ }^{109} \mathrm{Ag}$ was designated series $R \& D$, sample 000201. The certificate which accompanicd each sample showed enrichment to better than 99.9 percent for the major isotope. No information on chemical purity was given.

Since the method developed for the assay of silver was based on the precipitation of AgI from ammonical solution, it was necessary lo develop a purification procedure that would reduce possible impurities to a level low enough so they would not eause a significant error.

Elements that form relatively insoluble iodides or hydroxides could possibly interfere. Included are $\mathrm{Pb}$, and $\mathrm{Tl}$ which form insoluble iodides, and $\mathrm{Al}, \mathrm{Cr}, \mathrm{Fe}, \mathrm{Ga}, \mathrm{ln}, \mathrm{Ti}, \mathrm{Zr}$, and the rare earths which form insoluble hydroxides.

Each separated silver isotope was purified as follows: The silver isotope, as powdered silver metal (about $\mathrm{lg}$ ) was transferred to a $150 \mathrm{~mL}$ Teflon-FEP beaker, dissolved in $20 \mathrm{~mL}$ of $(\mathrm{l}+4) \mathrm{HNO}_{3}$, and the resulting solution evaporated to dryness. The residue was taken up in $50 \mathrm{~mL}$ of water and enough concentrated $\mathrm{NH}_{4} \mathrm{OH}$ solution to dissolve the precipitated $\mathrm{AgOH}$. The solution was digested on a warm hot plate for about one hour, allowed to cool, and filtered through a elose textured paper. After washing the filtcr paper with dilute $(1+49) \mathrm{NH}_{4} \mathrm{OH}$ the filtrate was heated to drive most of the $\mathrm{NH}_{3}$ from the solution. The solution was made acidie with dilute $(1+9) \mathrm{HNO}_{3}$ and $25 \mathrm{~mL}$ of $(1+9) \mathrm{HCl}$ was added to precipitate silver chloride. The solution and precipitate were digested on a hot plate for three hours in darkness and allowed to stand overnight at room temperature, also in darkness. Most of the supernatant slution was removed from the precipitated silver chloride by decantation and the last 10 $15 \mathrm{~mL}$ was withdrawn by means of a plastic syringe equipped with a platinum needle. The precipitated $\mathrm{AgCl}$ was washed three times with a few $\mathrm{mL}$ of $\mathrm{H}_{2} \mathrm{O}$ and the washings were removed with the syringe and needle.

The precipitated $\mathrm{AgCl}$ was then dissolved in $15 \mathrm{~mL}$ of $\mathrm{NH}_{4} \mathrm{OH}$ and diluted with about $50 \mathrm{~mL}$ of water. The solution was heated to drive off excess $\mathrm{NH}_{3}$ and made aeid with (1 $+9) \mathrm{HNO}_{3}$ to repreeipitate $\mathrm{AgCl}$. A few drops of $(\mathrm{l}+9)$ $\mathrm{HCl}$ were added and the solution was allowed to stand overnight in darkness. The supernatant liquid was then removed in the manner previously deseribed. The precipitated $\mathrm{AgCl}$ was then dissolved in $20 \mathrm{~mL}$ of $\mathrm{NH}_{4} \mathrm{OH}$ and transferred to a $350 \mathrm{~mL}$ platinum dish. A solution prepared by reacting 25 $\mathrm{mL}$ of $(\mathrm{l}+4) \mathrm{HNO}_{3}$ with $50 \mathrm{~mL}$ of $(1+4) \mathrm{NH}_{4} \mathrm{OH}$ yielding $\mathrm{NH}_{4} \mathrm{NO}_{3}$, was added as an electrolyte and the resulting solution was diluted to approximately $250 \mathrm{~mL}$. The platinum dish was placed on aluminum foil which was conneeted to the eathode of a de-power souree. The dish was covered with a Teflon-TFE eover fitted with a platinum rod through the middle whieh reached to within $1 \mathrm{~cm}$ of the dish bottom. This rod was connected to the anode of the dc-power source. Silver was then elcctrodepositcd onto the dish by plating with a potential of $1.0 \mathrm{~V}$ for $24 \mathrm{~h}$.

The elcctrolyte was then poured from the dish into a Teflon beaker and the electrodeposited silver in the dish was washed with dilute $(1+9) \mathrm{NH}_{4} \mathrm{OH}$.

The electrodeposited silver was dissolved with $(1+4)$ $\mathrm{HNO}_{3}$ diluted to about $150 \mathrm{~mL}$ and the solution was made ammonical with concentrated $\mathrm{NH}_{4} \mathrm{OH}$. Additional $\mathrm{NH}_{4} \mathrm{NO}_{3}$ electrulyte was added and the silver was again electrodeposited by plating at $1.0 \mathrm{~V}$ for $24 \mathrm{~h}$.

The electrolyte was then poured into the Teflon beakcr, and the silver was washed with watcr. The dish and contents werc then dried and weighed. The clectrodeposited silver was then dissolved with $(\mathrm{l}+4) \mathrm{HNO}_{3}$ and transferred to a Teflon bcaker. The dish was washed with water, dried, and weighed to obtain the approximate weight of purified silvcr. 
Caleulations based on the starting weight of silver, and the weight of purified silver showed that more than 99 percent of the silver was reeovered in each case.

The effectiveness of this purification procedure was first tested by purifying a solution of natural silver which had been doped at the $1000 \mu \mathrm{g} / \mathrm{g}$ level with each of thirty common impurity elements. The results of the analysis of this purified silver are shown in table 1 . All of the impurity elements were reduced to $10 \mu \mathrm{g} / \mathrm{g}$ or less (the analytical method will also be described later).

Sinee the method was effeetive in purifying grossly contaminated silver, it was applied to eaeh of the silver separated isotopes, which were of much higher initial purity.

The aeids and water used in these purifications were produeed at NBS by sub-boiling distillation [23] and have been shown to be extremely low in trace metal eontamination. The $\mathrm{NH}_{4} \mathrm{OH}$ was produeed by saturating high purity cold water with high-purity $\mathrm{NH}_{3}$ gas and allowing the resulting solution to warm to room temperature. Apparatus such as beakers and filters were eleaned with ACS Reagent Grade acids and rinsed with high purity water before use.

TABLE 1. Analysis of impurities in silver separated isotopes.

\begin{tabular}{|c|c|c|c|c|}
\hline Element & $\begin{array}{c}\text { Spike } \\
\text { Isotope }\end{array}$ & $\begin{array}{c}\text { Ag } \\
\text { Doped }^{\star} \text { and Purified } \\
(\mu \mathrm{g} / \mathrm{g})\end{array}$ & $\begin{array}{l}{ }^{107} \mathrm{Ag} \\
(\mu \mathrm{g} / \mathrm{g})\end{array}$ & $\begin{array}{r}{ }^{109} \mathrm{Ag} \\
(\mu g / g) \\
\end{array}$ \\
\hline $\mathrm{Al}$ & ${ }^{26} \mathrm{Mg}$ & 4 & $<14$ & $<20$ \\
\hline As & ${ }^{2} \mathrm{Se}$ & 0.3 & $-^{b}$ & - \\
\hline $\mathrm{Ba}$ & ${ }^{137} \mathrm{Ba}$ & 0.1 & 3.1 & 0.9 \\
\hline $\mathrm{Bi}$ & ${ }^{20 y} \mathrm{Tl}$ & 0.05 & - & - \\
\hline $\mathrm{Ca}$ & ${ }^{44} \mathrm{Ca}$ & 2.6 & 1.5 & 1 \\
\hline Cd & ${ }^{111} \mathrm{Cd}$ & 0.4 & 0.3 & 1,2 \\
\hline $\mathrm{Co}$ & ${ }^{62} \mathrm{Ni}$ & 0.5 & - & - \\
\hline $\mathrm{Cr}$ & ${ }^{w} \mathrm{Cr}$ & 0.2 & 0.2 & 0.1 \\
\hline $\mathrm{Cu}$ & ${ }^{a s} \mathrm{Cu}$ & 1.2 & 2.2 & 0.7 \\
\hline $\mathrm{Fe}$ & ${ }^{54} \mathrm{Fe}$ & 5 & 6 & 6 \\
\hline Ga & ${ }^{71} \mathrm{Ga}$ & 0.2 & $<1.1$ & $<1,6$ \\
\hline $\mathbf{K}$ & ${ }^{41} \mathrm{~K}$ & 2.7 & 5 & 1.2 \\
\hline $\mathbf{M g}$ & ${ }^{26} \mathrm{Mg}$ & 1.8 & 0.8 & 1.2 \\
\hline Mn & ${ }^{54} \mathrm{Fe}$ & 0.03 & - & - \\
\hline Mo & ${ }^{97} \mathrm{Mo}$ & 0.01 & 0.06 & 0.06 \\
\hline $\mathrm{Na}$ & ${ }^{41} \mathrm{~K}$ & 9 & $<50$ & $<60$ \\
\hline Nd & ${ }^{145} \mathrm{Nd}$ & 0.2 & 0.6 & 0.4 \\
\hline $\mathrm{Ni}$ & ${ }^{6} \mathrm{Ni}$ & 0.4 & 2 & 0.4 \\
\hline $\mathrm{Pb}$ & ${ }^{200} \mathrm{~Pb}$ & 1.6 & 1.5 & 1.6 \\
\hline Pd & ${ }^{110} \mathrm{Pd}$ & 0.2 & 0.8 & 0.2 \\
\hline $\mathrm{Sb}$ & ${ }^{117} \mathrm{~S} n$ & 0.6 & - & - \\
\hline Se & ${ }^{82} \mathrm{Se}$ & 0.2 & 0.3 & 0.4 \\
\hline $\mathrm{Sn}$ & ${ }^{117} \mathrm{Sn}$ & 0.07 & 0.3 & 0.4 \\
\hline Sr & ${ }^{\circ} \mathrm{Sr}$ & 0.03 & 0.1 & 0.1 \\
\hline $\mathrm{Te}$ & ${ }^{125} \mathrm{Te}$ & 0.002 & 0.1 & 0.07 \\
\hline Tl & ${ }^{20 y} \mathrm{Tl}$ & 0.1 & 0.5 & 0.5 \\
\hline $\mathrm{v}$ & ${ }^{53} \mathrm{Cr}_{\mathrm{r}}$ & 0.03 & - & - \\
\hline $\mathrm{Zn}$ & ${ }^{67} \mathrm{Zn}$ & 1 & 0.3 & 0.6 \\
\hline $\mathrm{Zr}$ & ${ }^{91} \mathrm{Zr}$ & 0.06 & 0.5 & 0.6 \\
\hline
\end{tabular}

- Original concentration- $1000 \mu \mathrm{g} / \mathrm{g}$ each.

b - denotes dala not reported.

\subsection{Preparation and Analysis of Separated Isotope Solutions}

Each isotope $\left({ }^{107} \mathrm{Ag}\right.$ and $\left.{ }^{109} \mathrm{Ag}\right)$ was transferred to a specially constructed and tared $500 \mathrm{~mL}$ quartz flask. These flasks were constructed from a standard taper joint $500 \mathrm{~mL}$ quartz flask by cutting the neck of the flask about $1 \mathrm{~cm}$ from the body and tooling the neck to fit a number zero polyethylene stopper and a standard aluminum serum cap. Final solutions were diluted to about $350 \mathrm{~mL}$ and final acidity was about $0.5 \mathrm{~N} \mathrm{HNO}_{3}$. The solution of ${ }^{107} \mathrm{Ag}$ was labeled "Ag-107" and the solution of ${ }^{109} \mathrm{Ag}$ was labeled "Ag-109".

Portions of eaeh separated isotope solution, equivalent to about $40 \mathrm{mg}$ of silver, were taken for determination of impurities. Each sample was spiked with $10^{-7} \mathrm{~g}$ of ${ }^{44} \mathrm{Ca},{ }^{111} \mathrm{Cd}$, ${ }^{53} \mathrm{Cr},{ }^{65} \mathrm{Cu},{ }^{54} \mathrm{Fe},{ }^{71} \mathrm{Ga},{ }^{26} \mathrm{Mg},{ }^{97} \mathrm{Mo},{ }^{145} \mathrm{Nd},{ }^{62} \mathrm{Ni},{ }^{206} \mathrm{~Pb},{ }^{110} \mathrm{Pd}$, ${ }^{82} \mathrm{Se},{ }^{117} \mathrm{Sn},{ }^{86} \mathrm{Sr},{ }^{125} \mathrm{Te},{ }^{203} \mathrm{Tl},{ }^{67} \mathrm{Zn}$, and ${ }^{91} \mathrm{Zr}$. Each spiked solution was then treated as follows: the solution was diluted to about $40 \mathrm{~mL}$ with $\mathrm{H}_{2} \mathrm{O}$ and a slight excess of $\mathrm{HCl}$ was added to precipitate $\mathrm{AgCl}$. The beaker and contents were allowed to stand in the dark overnight. Most of the supernatant liquid was removed from the precipitated $\mathrm{AgCl}$ by decantation into a second Tellon beaker. The last approximately $10 \mathrm{~mL}$ was removed by means of a plastic syringe and platinum needle and added to the decanted solution. The precipitate was washed with a few $\mathrm{mL}$ of $(1+9) \mathrm{HNO}_{3}$ which was also combined with the decanted solution by use of the syringe. This solution was then evaporated to a few $\mathrm{mL}$, removed from any remaining $\mathrm{AgCl}$ with the syringe and transferred to another beaker. This solution was evaporated to a large drop and transferred to specially prepared gold wire electrodes for analysis by spark source mass spectrometry using a peak switching electronic detection system.

The results of the anslysis of the purified separated silver isolopes are shown in table 1 . In addition to the spiked elements, the concentrations of other elements were estimated by eomparison to spiked nuelides using the assumption that the sensitivity of the natural element and spike nuclides are the same. The results show that most elements are al the low ppm level or less. The only elements found at concentrations of greater than $10 \mathrm{ppm}$ were $\mathrm{Al}$ and $\mathrm{Na}$. These contaminants may have resulted from the Pyrex glass flask used to store the spike isotopes. Even if they were present in the amounts indicated, the effect would be negligible since sodium would not interfere with the analysis at this level, and aluminum, as $\mathrm{Al}(\mathrm{OH})_{3}$, would cause an error of only 0.001 percent in the assay of each isotope.

\subsection{Assay of the Separated Isotope Solutions}

The method developed for the high-preeision assay of the silver solutions was based on a combination of gravimetry for the determination of most of the silver (greater than 99.5 
percent) as AgI and isotope dilution mass spectrometry (IDMS) for the remainder. Silver iodide was seleeted as the gravimetric form since, of all the silver halides it is the least light sensitive, least soluble, and has the highest gravimetric factor. In fact, it was found that dry stoichiometric silver iodide was not detectably sensitive to fluorescent lighting since the material remained lemon yellow and no change in weight could be detected on prolonged exposure. The material was also found to be non-hygroscopic up to relative humidities of 90 percent.

The "Ag-107" solution and the "Ag-109" solution were each sampled for assay of silver in the following manner: four weighed portions of about $35 \mathrm{~g}$, containing about $0.25 \mathrm{mmol}$ Ag were withdrawn from each flask. A $10 \mathrm{~cm}$ platinum needle which had been inserted through a No. 0 polyethylene stopper was used to replace the stopper on the quartz flask. A $20 \mathrm{~mL}$ polyethylene hypodermic syringe, the plunger of which had becn covered with a sheet of Teflon-FEP, was attached to the Kel-F hub of the needle and the desired amount of solution was withdrawn. The syringe was then disconnected from thc hub and the tip was capped with a Kel-F cap. The syringe and contents were then weighed on a semi-micro balance to $\pm 0.02 \mathrm{mg}$. (Any static charge on the syringe was dissipated by placing the syringe on the balance pan which was surrounded by several polonium anti-static sources and waiting 2 min before taking a weight.) The solution was then delivered to a $100 \mathrm{~mL}$ Pyrcx beaker with a Teflon coated rim and the syringe was again capped and weighed. The weight of the sample taken was determined from the weight of the syringe before and after delivery of the sample. A second weighed portion $w^{\prime}:$ taken in the same manner and combined with the first pution for each assay sample. Two assay samples were withdrawn from eaeh solution before and after withdrawing the calibration samples to cnsure that no change in coneentration had occurred during the time interval of withdrawing samples (about 6h).

Each sample was then assayed as follows: $20 \mathrm{~mL}$ of concentrated high-purity $\mathrm{NH}_{4} \mathrm{OH}$ was added and approximately a 1 percent excess of $0.5 \mathrm{~N} \mathrm{NH}_{4} \mathrm{I}$ was added slowly from a small wash bottle. The solution was heated covered on a hot plate.

Precipitation from ammonical solution resulted in the formation of a white precipitate, $\mathrm{AgI} \cdot 1 / 2 \mathrm{NH}_{3}$ [24]. Heating the solution drives off ammonia and results in the conversion of this white compound into yellow AgI. The AgI formed in this manner is composed of relatively large, easily filtcrable crystals that do not pass into the colloidal state when washed with water. The faet that $\mathrm{AgI}$ is slightly soluble in dilute $\mathrm{NH}_{4} \mathrm{OH}$ also contributes to the formation of larger crystals.

After digesting overnight, the cover was removed and the solution was evaporated to a volume of $20 \mathrm{~mL}$. Removal of $\mathrm{NH}_{3}$ was tested by holding moist $\mathrm{p}$-Hydrion paper over the hot solutions. If the paper indicated $\mathrm{NH}_{3}$ in the vapor the solution was heated until $\mathrm{NH}_{3}$ was no longer detected. The beaker was then removed from the hot plate, covered, and allowed to stand overnight.

The solution was then filtered through a tared platinumMunroe crucible and the preeipitated AgI was eaught on the platinum mat. The beaker and precipitate were washed with several small increments of water. The filtrate and washing were transferred back to the original beaker and reserved for the determination of dissolved and untransferred silver. The erucible and contents were dried for $3 \mathrm{~h}$ at $200^{\circ} \mathrm{C}$. Pure AgI is only very slightly reduced by light when wet. To guard against any possible deeomposition, the precipitation, filtration, and drying were carried out in orange light or darkness. (The pure compound is lemon yellow and even slight deeomposition causes the Agl to darken.)

After heating, the crucible was cooled in a desiceator and transferred to the ease of a micro-balance and allowed to stand for at least $2 \mathrm{~h}$. The erucible and contents were then weighed on a micro-balance to $\pm 0.002 \mathrm{mg}$. An effective buoyancy and adsorption correction for the platinum crucible was made by averaging three empty tare crucibles. (The drying, cooling, and weighing wcre repeated to ensure constant weight.) The apparent mass of the AgI was then determined and converted to true mass using a $5.66 \mathrm{~g} \mathrm{~cm}^{-3}$ for the density of ${ }^{107} \mathrm{AgI}$ and $5.71 \mathrm{~g} \cdot \mathrm{cm}^{-3}$ for the density of ${ }^{109} \mathrm{AgI}$. These densities were calculated by assuming that they are proportional to the density of natural $\alpha \mathrm{AgI}, D^{30}=5.68 \mathrm{~g} \cdot \mathrm{cm}^{-3}$, in the same ratio as their molecular weights. The vacuum weight of the silver iodide was converted to millimoles of silver using the ealculated atomic weight for silver and 120.9045 for iodine. The formula weights used were 233.8909 for ${ }^{107} \mathrm{AgI}$ and 235.8087 for ${ }^{109} \mathrm{AgI}$.

To determine the soluble and untransferred silver, the filtrate and washings, which had been reserved in the original beaker, were spiked with 1 to $2 \mu \mathrm{mol}$ of either ${ }^{107} \mathrm{Ag}$ or ${ }^{109} \mathrm{Ag}$. Five $\mathrm{mL}$ of ammonium hydroxide solution and $0.25 \mathrm{~g}$ of potassium cyanide (ACS Reagent Grade) were added to dissolve silver iodide and the solution was well mixed by stirring with a magnetie stirring bar for a few hours. Silver was then separated electrolytically by plating ovcrnight with a potential of $2.6 \mathrm{~V}$ onto a platinum wire anode. Silver was then dissolved from the electrode with a few $\mathrm{mL}$ of $(1+1) \mathrm{HNO}_{3}$ and the resulting solution was evaporated to dyrness. The residue was taken up in $(1+49) \mathrm{HNO}_{3}$ and the $107 / 109$ ratio was determined by surface ionization mass spectrometry. The amount of silver as $\mu \mathrm{mol}$ of $\mathrm{Ag}$ was then calculated and added to the silver from the gravimetric determination to yield the total silver in the sample.

This method of assaying silver solutions was first tested on solutions containing known amounts of silver. The material was SRM 748 which is 99.999 + percent silver. The solutions were prepared in the approximate concentration range of 0.10 to $0.16 \mathrm{mmol}$ AgI. Four portions eontaining from 0.9 to 1.1 
$\mathrm{mmol} \mathrm{Ag}$ were withdrawn from each solution and silver was determined as deseribed above. Nine sets of four samples were analyzed in this manner.

Statistieal analysis of the data from these nine sets showed that the standard error of the mean of four values was $5.2 \times$ $10^{-6} \mathrm{mmol} / \mathrm{g}$ and that the coeffieient of variation (standard error/mean) for a set of four was 0.003 percent. Comparison of caleulated to measured eoncentrations showed a small positive bias of about 0.005 percent, but this would have a negligible effect on the ratio of two assays.

The results of the assay of the separated isotope solutions are shown in table 2. Pooling the results of the assay of the separated isotope solutions and the nine sets of natural solutions, yields a value of $0.0000009 \mathrm{mmol} \mathrm{Ag/g}$ for the standard error of the average eoncentration of each separated isotope solution. The uncertainty associated with this value at the 95 percent confidence level is $1.8 \times 10^{-6} \mathrm{mmol} \mathrm{Ag} /$ g.

\subsection{Isotopic Analyses of the Separafed Isotope Solutions}

Each of the separated isotope solutions was analyzed eight times on each of two mass spectrometers, MS \#l and MS \#5, by Operators $l$ and 2, respectively. The mass spectrom- eter sources were cleaned between the analyses of the ${ }^{107} \mathrm{Ag}$ and ${ }^{109} \mathrm{Ag}$ as a precaution against the possibility of contamination from source parts, although back-to-back analyses of the two separated isotopes on the same source failed to yield any evidenee of contamination. The eorrected isotopie compositions of the two isotopes arc shown in table 3 .

The measured impreeision of the ratio measurements for each of the separated isotope solutions was less than 3 percent (2 standard deviations), however an uncertainty of 7 percent was placed on the ratios for the separated isotopes to cover possible measurement system nonlincarities and isobaric interferences. Several possible species have a polential for produeing isobaric interferences in the silver mass region. These include $\mathrm{CaPO}_{2}^{+}, \mathrm{SiPO}_{3}^{+}$, and $\mathrm{AsS}^{+}$. Any interferences from $\mathrm{CaPO}_{2}^{+}$can be detected by monitoring mass 103 whieh results from the major isotope of caleium $\left({ }^{40} \mathrm{Ca}: 96.9\right.$ pereent abundant). However, the major isotopes of silicon and sulfur would produce $\mathrm{SiPO}_{3}^{+}$and $\mathrm{AsS}^{+}$interferences at mass 107. Thus extremely small quantities of either of these speeies could not be detected by examining other masses in the silver spectral region. $\mathrm{A} \mathrm{SiPO}_{3}^{+}$species has not been reported or observed in a thermal ionization-silica gel analysis but is included herein because of the nearly infinite supply of these elements on the filament, and the faet that an intense and

TABLE 2. Concentration of silver separated isotope solution

\begin{tabular}{|c|c|c|c|c|c|c|c|}
\hline Solution & $\begin{array}{c}\text { Sample } \\
\text { No. }\end{array}$ & $\begin{array}{l}\text { Weight } \\
\mathrm{Ag} \mathrm{I} \\
\text { (g) }\end{array}$ & $\begin{array}{c}\text { Ag from } \\
\text { Ag I } \\
\text { (mmol) }\end{array}$ & $\begin{array}{l}A_{g} \text { from } \\
\text { Filtrate } \\
\text { (mmol) }\end{array}$ & $\begin{array}{c}\text { Toual } \\
\mathrm{Ag} \\
\text { (mmol) }\end{array}$ & $\begin{array}{c}\text { Weighı } \\
\text { Sample } \\
\text { (g) }\end{array}$ & $\begin{array}{c}\text { Concentration } \\
(\mathrm{mmol} \mathrm{Ag} / \mathrm{g})\end{array}$ \\
\hline "Ag 107" & $\begin{array}{l}1 \\
2 \\
3 \\
4\end{array}$ & $\begin{array}{l}0.223445 \\
0.231677 \\
0.234055 \\
0.228265\end{array}$ & $\begin{array}{l}0.955668 \\
0.990876 \\
1.001047 \\
0.976283\end{array}$ & $\begin{array}{l}0.002583 \\
0.002358 \\
0.001176 \\
0.001211\end{array}$ & $\begin{array}{l}0.958251 \\
0.993234 \\
1.002223 \\
0.977493\end{array}$ & $\begin{array}{l}34.00905 \\
35.25092 \\
35.56893 \\
34.69020\end{array}$ & $\begin{array}{l}0.0281760 \\
0.0281761 \\
0.0281769 \\
0.0281778\end{array}$ \\
\hline \multicolumn{7}{|r|}{ Average } & 0.0281767 \\
\hline "Ag $109 "$ & $\begin{array}{l}1 \\
2 \\
3 \\
4\end{array}$ & $\begin{array}{l}0.229478 \\
0.228795 \\
0.226974 \\
0.231376\end{array}$ & $\begin{array}{l}0.973153 \\
0.970257 \\
0.962534 \\
0.981202\end{array}$ & $\begin{array}{l}0.003956 \\
0.002316 \\
0.001029 \\
0.001614\end{array}$ & $\begin{array}{l}0.977109 \\
0.972573 \\
0.963563 \\
0.982814\end{array}$ & $\begin{array}{l}35.78498 \\
35.62279 \\
35.28974 \\
35.99738\end{array}$ & $\begin{array}{l}0.0273050 \\
0.0273020 \\
0.0273044 \\
0.0273024\end{array}$ \\
\hline \multicolumn{7}{|r|}{ Average } & 0.0273034 \\
\hline
\end{tabular}

TABLE 3. Isotopic composition of the silver separated isotopes

\begin{tabular}{cc|c}
\hline Separated Isolope & $\begin{array}{c}\text { Isolopic Composition } \\
\text { (atom percent) }\end{array}$ \\
\hline "Ag 107" & ${ }^{107} \mathrm{Ag}$ & $99.97136 \pm 0.00206$ \\
& ${ }^{109} \mathrm{Ag}$ & $0.02863 \pm 0.00206$ \\
“Ag 109" & ${ }^{107} \mathrm{Ag}$ & $0.02865 \pm 0.00203^{\circ}$ \\
& ${ }^{109} \mathrm{Ag}$ & $99.97135 \pm 0.00203$ \\
\hline
\end{tabular}

- The uncerlainly of the ratio determination is taken to be 7 percent, which is much larger than the 95 percent confidence limit, to take into account possible biases and non-linear instrumental behavior for ratios as large as these. 
sustained $\mathrm{PO}_{3}^{-}$ion beam is observed in the negative ion spectra under the analytical conditions reported in this paper.

Kelly and Wasserburg [25] reported the existence of AsS ${ }^{+}$ which, if present, would enhance the measured 107/109 ratio. The measurement of the ${ }^{109} \mathrm{Ag}$ separated isotope is particularly sensitive to this interference because $\mathrm{AsS}^{+}$would produce a $107 / 109$ ratio of 22 . Efforts to generate as $\mathrm{AsS}^{+}$ion beam by loading $\mathrm{As}_{2} \mathrm{~S}_{3}$ and $\mathrm{H}_{2} \mathrm{SO}_{4}$ onto the filament using the procedure described in section 2 were unsuccessful. Since the silver was loaded in $(1+9) \mathrm{HNO}_{3}$, it is felt that the nitric acid allowed oxidation of the sulfur to sulfate, thus reducing any $\mathrm{AsS}^{+}$to an undetectable level.

Analysis under identical conditions of ${ }^{109} \mathrm{Ag}$ samples ranging in amount from $4 \mu \mathrm{g}$ to $0.005 \mu \mathrm{g}$ indicated a possible mass-107 isobaric interference at a level of $1( \pm 1) \times 10^{-16}$ A. This level of interference is below the direct measurement detection limit of the instrument but can be inferred from the slight decrease in the observed 109/107 ratio with decreasing sample size. This suspected interference would produce a bias of approximately 2 percent to the observed ratios of the ${ }^{109} \mathrm{Ag}$ separated isolope and a bias of approximately 0.002 percent to the observed ratios of the reference sample and the calibration mixes.

\subsection{Preparation of Calibration Samples}

Eight calibration mixes were prepared by blending weighed portions of the "Ag-107" and the "Ag-109" solutions to pro- duce $107 / 109$ ratios ranging from 0.5 to 2.0 . Six of the calibration mixes were within a few percent of the natural ratio $107 / 109$ of 1.076 .

The portions for mixing were withdrawn from the flasks and weighed in the manner previously described for the assay of each solution. Each portion wieghed about $10 \mathrm{~g}$ and was weighed to $\pm 0.05 \mathrm{mg}$. lt is therefore estimated that the weighing error for each mix should not exceed one part in $10^{5}$. To minimize any significant possibility of change in concentration of the isotope solutions with time, the portions for the calibration mixes were withdrawn from the flasks between the samples taken for assay, over a period of about $6 \mathrm{~h}$.

Each calibration mix was thoroughly mixed, the sides of the beaker were washed with water, and the solution was evaporated to dryness. The residue was taken up wilh dilute $(1+9) \mathrm{HNO}_{3}$ and the mixing, washing, and evaporation were repeated. The calibration mixes were then taken up in $(1+9) \mathrm{HNO}_{3}$ to a concentration of $0.8 \mathrm{mg} \mathrm{Ag} / \mathrm{mL}$ and transferred to small Teflon bottles. The isotopic compositions of the calibration mixes are given in table 4 .

\subsection{Isotopic Analyses of the Calibration Mixes and the Standard Sample}

Two complete sets of analyses of the calibration mixes and reference sample were performed by 0 perator 1 on MS \#1 and Operator 2 on MS \#5. Operator 1 performed three anal-

TAELE 4. Isolopic composition of calibration mixes

\begin{tabular}{|c|c|c|c|c|c|c|c|c|}
\hline $\begin{array}{c}\text { Solution } \\
\text { No. }\end{array}$ & $\begin{array}{l}\text { Isotope } \\
\text { Solution. }\end{array}$ & $\begin{array}{c}\text { Weight } \\
\text { Solution } \\
\text { (g) }\end{array}$ & $\begin{array}{c}\text { Ag from } \\
\text { Solution } \\
\text { (minol) }\end{array}$ & $\begin{array}{c}{ }^{107} \mathrm{Ag} \\
\text { Irom } \\
\text { Solution } \\
\text { (mmol) } \\
\end{array}$ & $\begin{array}{l}{ }^{1 * 9} \mathrm{Ag} \\
\text { from } \\
\text { Solution } \\
\text { [mmol) } \\
\end{array}$ & $\begin{array}{c}\text { Total } \\
{ }^{107} \mathrm{Ag} \\
\text { [mmol } \\
\end{array}$ & $\begin{array}{c}\text { Total } \\
\operatorname{lno}_{\mathrm{Ag}} \\
\text { (mmol) } \\
\end{array}$ & $\begin{array}{c}\text { Ralio } \\
107 / 109\end{array}$ \\
\hline 1 & $\begin{array}{l}\text { "Ag 107" } \\
" \mathrm{Ag} 109 "\end{array}$ & $\begin{array}{r}10.02135 \\
9.64836\end{array}$ & $\begin{array}{l}0.282369 \\
0.263433\end{array}$ & $\begin{array}{l}0.282288 \\
0.000076\end{array}$ & $\begin{array}{l}0.000081 \\
0.263358\end{array}$ & 0.282364 & 0.263439 & 0.07184 \\
\hline 2 & $\begin{array}{l}\text { "Ag 107" } \\
\text { "Ag 109" }\end{array}$ & $\begin{array}{l}8.95832 \\
6.68835\end{array}$ & $\begin{array}{l}0.252416 \\
0.237222\end{array}$ & $\begin{array}{l}0.252344 \\
0.000068\end{array}$ & $\begin{array}{l}0.000072 \\
0.237154\end{array}$ & 0.252112 & 0.237226 & 1.06402 \\
\hline 3 & $\begin{array}{l}\text { "Ag 107" } \\
\text { "Ag 109" }\end{array}$ & $\begin{array}{l}9.24458 \\
8.90162\end{array}$ & $\begin{array}{l}0.260482 \\
0.243044\end{array}$ & $\begin{array}{l}0.260407 \\
0.000070\end{array}$ & $\begin{array}{l}0.000075 \\
0.242974\end{array}$ & 0.260477 & 0.243049 & 1.07171 \\
\hline 4 & $\begin{array}{l}\text { "Ag } 107 " \\
" A_{g} 109 "\end{array}$ & $\begin{array}{l}9.756 .36 \\
9.42110\end{array}$ & $\begin{array}{l}0.274902 \\
0.257228\end{array}$ & $\begin{array}{l}0.274823 \\
0.000074\end{array}$ & $\begin{array}{l}0.000079 \\
0.257154\end{array}$ & 0.274897 & 0.257233 & 0.06867 \\
\hline 5 & $\begin{array}{l}\text { "Ag 107" } \\
\text { "Ag 109" }\end{array}$ & $\begin{array}{l}9.59357 \\
9.11603\end{array}$ & $\begin{array}{l}0.270315 \\
0.248899\end{array}$ & $\begin{array}{l}0.270237 \\
0.000071\end{array}$ & $\begin{array}{l}0.000078 \\
0.248828\end{array}$ & 0.270309 & 0.248906 & 1.08599 \\
\hline 6 & $\begin{array}{l}\text { "Ag 107" } \\
" A_{E} 109 "\end{array}$ & $\begin{array}{r}10.11275 \\
9.87378\end{array}$ & $\begin{array}{l}0.284944 \\
0.269588\end{array}$ & $\begin{array}{l}0.284862 \\
0.000078\end{array}$ & $\begin{array}{l}0.000082 \\
0.269511\end{array}$ & 0.284940 & 0.269592 & 1.05693 \\
\hline 7 & $\begin{array}{l}\text { "Ag 107" } \\
\text { "Ag 109" }\end{array}$ & $\begin{array}{l}10.01824 \\
18.94756\end{array}$ & $\begin{array}{l}0.282281 \\
0.517333\end{array}$ & $\begin{array}{l}0.282200 \\
0.000148\end{array}$ & $\begin{array}{l}0.000081 \\
0.517185\end{array}$ & 0.282348 & 0.517264 & 0.545849 \\
\hline 8 & $\begin{array}{l}\text { "Ag 107" } \\
\text { "Ag 109" }\end{array}$ & $\begin{array}{r}18.47706 \\
9.90908\end{array}$ & $\begin{array}{l}0.520623 \\
0.270552\end{array}$ & $\begin{array}{l}0.520474 \\
0.000078\end{array}$ & $\begin{array}{l}0.000119 \\
0.270475\end{array}$ & 0.520552 & 0.270624 & 1.92353 \\
\hline
\end{tabular}


yses of each ealibration mix and 24 analyses of the reference sample. Operator 2 performed four analyses of eaeh calibration mix and 32 analyses of the reference sample. The samples were run in a pattern alternating randomly seleeted mixes with the reference sample.

\section{Results and Discussion}

The results of the measurement of the eight calibration mixes are shown in table 5 . The calibration factors for each analyst varied over a range of 0.011 percent for Operator 1 and 0.019 percent for Operator 2 . In addition, the calibration factors for those mixes with a $107 / 109=2$ and $107 / 109=$ 0.5 were indistinguishable from those bracketing the reference sample, indicating an insignificant degree of nonlinearity over the measured range.

Table 6 summarizes the observed and corrected ${ }^{107} \mathrm{Ag} /$ ${ }^{109} \mathrm{Ag}$ values for the SRM for Operators 1 and 2 as well as the absolute isotopic abundance ratio for silver and its uncertainty.

Table 7 gives summary calculations of the referenee sample. The atonic weight is calculated from the absolute isotopic abundance by summing the product of the nuclidic masses obtained from Wapstra and Bos [17] and the corresponding atom fractions.
The atomie weight of silver, $107.868 \pm 0.001$, as recommended by the IUPAC Commission on Atomie Weights, is based on the isotopie abundance measurements reported by Shields, Gamer, and Dibeler [1] in 1962. This ratio is, in fact, the average of their isotopic abundanee measurements published in 1960 [26] and the results of the mineral survey described in the 1962 publication.

A reanalysis of sample $\mathrm{C}-140$, a nugget of native silver from Ontario, Canada, which had yielded anomalous data in the 1962 study [1], was undertaken. One section of this nugget, referred to as position 1 , had yielded a ratio of ${ }^{107} \mathrm{Ag} /$ ${ }^{109} \mathrm{Ag}$ which was 0.3 percent higher than three other sections, designated positions 2,3 , and 4 ; all of which mirrored the ${ }^{107} \mathrm{Ag} /{ }^{109} \mathrm{Ag}$ ratio of the natural silver reference sample (SRM 948). At the time, little or no chemistry was performed to purify the samples prior to analysis, and it was believed that the "anomaly" might be due to natural differences or chemical impurities. A reanalysis of the four sections of C-140, confirmed that position 1 yielded a ${ }^{107} \mathrm{Ag} /{ }^{109} \mathrm{Ag}$ ratio that was higher than the ratios for positions 2,3 , and 4 , which again yielded ratios indistinguishable from the natural silver reference standard. Subsequent analyses indicated the major impurity at position 1 was mercury. Following purification by eleetrodeposition and ion exchange chromatography, the ${ }^{107} \mathrm{Ag} /$ ${ }^{109} \mathrm{Ag}$ ratio for position 1 matched the ratios obtained for

TABLE 5. Determination of correction factors

\begin{tabular}{|c|c|c|c|c|c|}
\hline \multirow{2}{*}{$\begin{array}{l}\text { Calibration } \\
\text { Sample No. }\end{array}$} & \multicolumn{3}{|c|}{ Isotopic Ratio, ${ }^{107} \mathrm{Ag} /{ }^{1(1)} \mathrm{Ag}$} & \multicolumn{2}{|c|}{ Correction Factors } \\
\hline & Calculated & Operator 1 & Operator 2 & Operator 1 & Operator 2 \\
\hline 1 & 1.071840 & 1.081566 & 1.081420 & 0.99100367 & 0.99114511 \\
\hline 2 & 1.064016 & 1.073622 & 1.073579 & 0.99104924 & 0.99109658 \\
\hline 3 & 1.071705 & 1.081345 & 1.081214 & 0.99108175 & 0.99120936 \\
\hline 4 & 1.068671 & 1.078304 & 1.078236 & 0.99106309 & 0.99113312 \\
\hline 5 & 1.085996 & 1.095850 & 1.095681 & 0.99100465 & 0.99116505 \\
\hline 6 & 1.056931 & 1.066516 & 1.066407 & 0.99100878 & 0.99111770 \\
\hline 7 & 0.5458493 & 0.5507895 & 0.5506505 & 0.99102567 & 0.99128580 \\
\hline 8 & 1.923532 & 1.941050 & 1.940748 & 0.99097136 & 0.99113254 \\
\hline \multicolumn{4}{|c|}{ Mean Values of Calibration Factors } & 0.9910261 & 0.9911607 \\
\hline
\end{tabular}

TABLE 6. Determination of corrected isotopic ratios

\begin{tabular}{l|c|c|c}
\hline & $\begin{array}{c}\text { Observed } \\
{ }^{107} \mathrm{Ag} /{ }^{109} \mathrm{Ag}\end{array}$ & $\begin{array}{c}\text { Correction } \\
\text { Faclor }\end{array}$ & $\begin{array}{c}\text { Correclcd } \\
{ }^{107} \mathrm{Ag} /{ }^{109} \mathrm{Ag}\end{array}$ \\
\hline Operator 1 & 1.0861089 & 0.9910261 & 1.076362 \\
Operator 2 & 1.0859898 & 0.9911607 & 1.076390 \\
& & MEAN & 1.07638 \\
& & \pm & 0.00022 \\
\hline
\end{tabular}

\footnotetext{
Uncertainty components:

95 percent confidence limits in ratio determination ... $\quad \pm 0.00003$

Bounds due to possible systematic error in composition

of separated isolopes . . . . . . . . . . . $\quad \pm 0.00009$

Bounds due to possible systematic crror in chemical

analysis. . . . . . . . . . . . . . . \pm 0.00010
} 
TABLE 7. Summary calculations of the alamic weight of silver

\begin{tabular}{|c|c|c|c|c|}
\hline \multirow[b]{2}{*}{ Values } & \multicolumn{4}{|c|}{ Uncertainty Components } \\
\hline & Overall Limit of Error & $\begin{array}{l}\text { Mass Spectrometric } \\
\text { Analytical Error }\end{array}$ & $\begin{array}{l}\text { Possible Systemalic } \\
\text { Error in Composition of } \\
\text { Separaled Isolopes }\end{array}$ & $\begin{array}{c}\text { Possible Systematic } \\
\text { Error in Chemical } \\
\text { Analysis }\end{array}$ \\
\hline Atomic Weight $=107.86815$ & $\pm 0.00011^{\mathrm{tr}}$ & \pm 0.0000137 & \pm 0.0000408 & \pm 0.0000466 \\
\hline $\begin{array}{l}\text { Nuclidic Masses } \\
\qquad \begin{aligned}\left({ }^{12} \mathrm{C}=12\right) \\
{ }^{107} \mathrm{Ag}=106.905095 \\
{ }^{100} \mathrm{Ag}=108.904754\end{aligned}\end{array}$ & $\begin{array}{l} \pm 0.000012 \\
\pm 0.000010\end{array}$ & & & \\
\hline $\begin{array}{l}\text { Aloın Percent } \\
\qquad \begin{array}{l}{ }^{117} \mathrm{Ag}=51.839170 \\
{ }^{100} \mathrm{Ag}=48.160830\end{array}\end{array}$ & $\begin{array}{l} \pm 0.005057 \\
\pm 0.005057\end{array}$ & $\begin{array}{l} \pm 0.000687 \\
\pm 0.000687\end{array}$ & $\begin{array}{l} \pm 0.00204 \\
\pm 0.00204\end{array}$ & $\begin{array}{l} \pm 0.00233 \\
\pm 0.00233\end{array}$ \\
\hline $\begin{array}{l}\text { Isolopic Ratio } \\
{ }^{107} \mathrm{Ag} /{ }^{109} \mathrm{Ag}\end{array}=1.07638$ & \pm 0.00022 & \pm 0.0000296 & \pm 0.0000880 & \pm 0.0001006 \\
\hline
\end{tabular}

a The overall limit of error is the sum of the 95 pereent confidence limits and the terms covering effects of known sources of possible syblematic error.

'Includes a component for uncertainty in nuclidic masses.

positions 2,3 , and 4 , and thus, the reference standard. This experiment clearly documents the critical importance of ehemical purification in the determination of accurate isotopic ratios and in establishing the limils for natural isotopic variations. The data reflecting the effects of purification on sample C-140 are shown in table 8.

TABle 8. Effect of Purification on C-14O

\begin{tabular}{l|c}
\multicolumn{1}{c|}{ Chemical Procedure } & $\begin{array}{c}\text { Corrected } \\
{ }^{107} \mathrm{Ag} /{ }^{109} \mathrm{Ag}\end{array}$ \\
\hline Initial Electrodeposition & 1.07686 \\
Additional Electrodeposition & 1.07676 \\
Anion Exchange, Precipitation and Electrodeposition & 1.07634 \\
\hline
\end{tabular}

"All ratios have been plaeed on an absolule basis using the absolute isotopic abundance ratio for silver from Table $7\left({ }^{107} \mathrm{Ag} /{ }^{110} \mathrm{Ag}=1.07638\right)$.

In an attempt to establish the limits of isotopic variability among eommercially available silver, a series of analyses were performed on silver metal samples of varying purity, which had been obtained from refineries throughout the world. The results are shown in table 9. With the exception of the marz grade silver from Materials Research Corporation, all samples yielded isotopic ratios which were in excellent agreement with the natural reference standard. Although a deviation of 7.6 parts in $10^{4}$ is small, it is not known whether the difference is real or an artifact due to a ehemical impurity. Additional testing of this material will be done in conjunetion with a more thorough mineral survey in the future.

The effect of this isotopic survey of commereial silver on the atomie weight is small. A recalculation of the atomic weight of silver based on the isotope ratios of these materials yields a value of $107.86816 \pm 0.00032$ at the 95 percent confidenee level, which is nearly identical to the alomic weight of the reference sample $(107.86815)$ as given in table 7 , the major difference existing in the uncertainty.

The reference sample used in this atomic weight determination will be issued as both an isotopic and assay Standard Rcference Material (SRM) and will be designated as SRM 978a. Its isotopic analysis was found to be experimentally

TABLE 9. Isotope Ratios of Commercial Silver

\begin{tabular}{l|c}
\hline \multicolumn{1}{c}{ Description $^{\mathrm{a}}$} & $\begin{array}{c}\text { Correcled } \\
{ }^{107} \mathrm{Ag} /{ }^{109} \mathrm{Ag}\end{array}$ \\
\hline \hline Needle Ag, 99.995\%, Engelhard, Indiana, USA & 1.07650 \\
$\mathrm{AgNO}_{3}, 99.999 \%$, Engelhard, Indiana, USA & 1.07633 \\
$\mathrm{Ag}$, Marz Grade, Materials Research Corp., USA & 1.07557 \\
$\mathrm{Ag}$, Single Crystal, Marz Grade, USA & 1.07622 \\
Refined Ag, Port Pirie, Ausıralia & 1.07634 \\
Ag, Normal Purity, Johnson Mathey, Canada & 1.07640 \\
Ag, High Purity, Cominco, TADANAC, Canada & 1.07648 \\
Refined Ag, Mixture of Swedish Ores & 1.07646 \\
Electrolytic Ag, Boliden Mine, Sweden & 1.07670 \\
Ag, Crystalline, Mexico & 1.07638 \\
Ag, 99.99+\%, Lima, Pcru & 1.07653 \\
Ag, Plata Fina, Granalla, Mexieo & 1.07656 \\
\hline
\end{tabular}

" All deseriptions are as stated by the producer. No further purity verificalion was made.

' All ratios have been placed on an absolute basis using the absolule isolopie abundance ratio for silver from table $7\left({ }^{107} \mathrm{Ag} /{ }^{100} \mathrm{Ag}=1.07638\right)$. 
identical to SRM 978, the major difference existing in the uncertainty placed on the measurement.

The redetermination of the atomic weight of silver has allowed the recalculation of the Faraday from the electrochemical equivalent of silver as determined by Bower and Davis [5], yielding a value of $96486.18 \pm 0.13 \mathrm{~A}_{\mathrm{NBS}} \cdot \mathrm{s} \cdot \mathrm{mol}^{-1}$ (one standard deviation). Further details of the calculation of this constant are given elsewhere in this issue of the Journal of Research [27].

The reduction of the overall uncertainty in the Faraday constant has allowed discernment of the discrepancies which existed between the Faraday determined from electrochemical experiments, and the Faraday calculated from other fundamental constants. It is expected that the new NBS value of the Faraday will be included in the 1981 CODATA least squares adjustment of the fundamental constants.

We are indebted to: Keith R. Eberhardt for statistical analysis; Paul J. Paulsen for analysis of the separated isotopes; Karen A. Brletic for isotope dilution analysis of many of the assay samples; William A. Bowman III for instrumental maintenance support; Joy J. Shoemaker and Theresa Sperow for skillful manuscript preparation; and our colleagues in the mass spectrometry group of the Inorganic Analytical Research Division for their helpful discussions.

We also wish to express our gratitude to Richard Davies, Execulive Director of the Silver Institute for his assistance in gathering the high purity silver metal samples and to the following companies for their contributions: Boliden Metall AB, Sweden; The Broken Hill Associated Smelters Proprietory Limited, Australia; Met-Mex Peńales, S. A. de C. V., Mexico; Empresa Minera Del Centra Del Peru; JohnsonMatthey, Lid., Canada.

We also wish to thank Oak Ridge National Laboratory for their special efforts to produce the high purity ${ }^{107} \mathrm{Ag}$ and ${ }^{109} \mathrm{Ag}$ isotopes which were so necessary for this work.

\section{References}

[1] Shields, W. R.: Camer, E. L.: Dibeler, V. H. Absolute Isotopic Abundance of Terrestrial Silver. J. Res. Nat. Bur. Stand, (U.S.). 66A(1): $1-3 ; 1962$ January-February.

(2) Shields, W. R.; Murphy, T. J.; Gamer, E. L.; Dibeler, V. H. Absolute Iotopic Abundance Ratio and the Atomic Weight of Chlorine. J. Amer. Chem. Soc. B4: 1519-1522: 1962 May 5.

[3] Shields, W. R.; Murphy, T. J.; Gamer, E. L. J. Res. Nat. Bur. Stand. (U.S.). 68.4(6): 589-592; 1964 November-December.

[4] Catanzaro, E. I.; Mughty, T. 1.; Gamer, E. L.: Shields. W. R. Absolute Iutopic Abundances Ratio and the Atomic Weight of Bromine. J. Res. Nat. Bur. Stand. (U.S.). 68,A6): 593-599; 1964 November-December.

(5) Shields, W. R.; Murphy, T. I.; Catanzam, E. I.: Garner, E. L Absolute Inotopic Abundance Ratio and the Atomic Weight of a Reference Sample of Chromium. J. Res. Nut. Bur. Stand. (U.S.). 70A(2): 193-197; 1966 March-April.
[6] Catanzaro, E. J.; Murphy, T. J.; Garner, E. L.; Shields, W'. R. Absolute Isotopic Abundance Ratios and Atomic Weight of Magnesium. J. Res. Nat. Bur. Stand. (U.S.). 70A(6): 453-458; 1966 November-December.

[7] Catanzaro, E. J.; Murphy, T. J.; Shields, W. R.; Garner, E. L. Absolute Isotopic Abundance Ratios of Common, Equal-Atom, and Radiogenic Lead Isotopic Standards. J. Res. Nat. Bur. Stand. (U.S.). 72A(3): 261267; 1968 May-June.

[8] Catanzaro, E. J.; Champion, C. E.; Garner, E. L.; Marinenko, G.; Sappenfield, K. M.; Shields, W. R. Standard Reference Materials: Basic Acid; Isotopic, and Assay Standard Reference Materials. Nat Bur. Stand. (U.S.) Spec. Publ. 260-17; 1970 February. 60 p.

[9] Catanzaro, E. J.; Murphy, T. J.; Garner, E. L.; Shields, W. R. Absolute Isotopic Abundance Ratio and Atomic Weight of Terrestrial Rubidium. J. Res. Nat. Bur. Stand. (U.S.). 73A(5): 511-516; 1969 SeptemberOctober.

[10] Gramlich, J. W.; Murphy, T. J.; Garner. E. L.; Shields, W. R. Absolute Isotopic Abundance Ratio and Atomic Weight of a Reference Sample of Rhenium. J. Res. Nat. Bur. Stand. (U.S.). 77A(6): 691-698; 1973 November-December.

[11] Barnes, I. L.; Moore, L. J.; Machlan, L. A.; Murphy, T. J.; Shields, W. R. Absolute Isotopic Abundance Ratios and the Atomic Weight of a Reference Sample of Silicon. J. Res. Nat. Bur. Stand. (U.S.). 79A(6): 727-735; 1975 November-December.

[12] Garner, E. L.; Murphy, T. J.; Gramlich, J. W.; Paulsen, P. J.; Barnes, I. L. Absolute Isotopic Abundance Ratios and the Atomic Weight of a Reference Sample of Potassium. J. Res. Nat. Bur. Stand. (U.S.). 79A(6): 713-725; 1975 November-December.

[13] Dunstan, L. P.; Gramlich, J. W.; Barnes, 1. L.; Purdy. W. C. Absolute Isotopic Abundance and the Atomic Weight of a Reference Sample of Thallium. J. Res. Nat. Bur. Stand. (U.S.). 85(1): 1-10; 1980 JanuaryFebruary.

[14] Moore, L. J.; Murphy, T. J.; Barnes, 1. L. Absolute Isotopic Abundance Ratios and Atomic Weight of a Reference Sample of Strontium. J. Res. Nat. Bur. Stand. (U.S.). 87(1): 1-8, 1982 January-February.

[15] Bower, V. E.; Davis, R. S. The Electrochemical Equivalent of Pure Silver-A Value of the Faraday. J. Res. Nat. Bur. Stand. (U.S.). 85(3): 175-191; 1980 May-June.

[16] Gamer, E. L; Machlan, L. A.; Shields, W. R. Standard Reference Materials: Uranium Isotopic Standard Reference Materials. Nat. Bur. Stand. (U.S.) Spec. Publ. 260-27; 1971 April. 162 p.

[17] Wapstra, A. H.; Bos, K. Atomic Data and Nuclear Data Tables. 19(3): 177-214; 1977 March.

[18] Shields, W. R., ed. Analytical Mass Spectrometry Section: Summary of Activities July 1966 to June 1967. Nat. Bur. Stand. (U.S.) Tech. Note 426; 1967 September. 53 p.

[19] Shields, W. R., ed. Analytical Mass Spectrometry Section: Instrumentation and Procedures for Isotopic Analysis. Nat. Bur. Stand. (U.S.) Tech. Note 277; 1966 July. 99 p.

[20] Gamer, E. L.; Machlan, L. A.; Shields, W. R. Standard Reference Materials: Uranium Isotopic Standard Reference Materials. Nat. Bur. Stand. (U.S.) Spec. Publ. 260-27; 1971 April. 150 p.

[21] Bames, I. L.; Murphy, T. J.; Gramlich, J. W.; Shields, W. R. Lead Separation by Anodic Deposition and Isotope Ratio Mass Spectrometry of Microgram and Smaller Samples. Anal. Chem. 45(11): 1881-1884; 1973 September.

[22] Gramlich, J. W.; Shideler, R. W. A Programmable Sample Dryer for Thermal lonization Mass Spectrometry. Nat. Bur. Stand. (U.S.) Tech. Note 1154, 1982.

[23] Kuehner, E. C.; Alvarez, R.; Paulsen, P. J.; Murphy, T. J. Production and Analysis of High Purity Acids Purified by Sub-boiling Distillation. Anal. Chem. 44(12): 2050-2056; 1972 October.

[24] Longe, W. Uber die Verfarburg des Silberjodids durch wässriges Ammoniak. Z. Ansrg u. Allgem. Chem. 223: 174-176; 1935. 
[25] Kelly, W. R.: Tera, F.; Wasserburg, G. J. Isotopic Determination of Silver on Picomole Quantities by Surface Ionization Mass Spectrometry. Anal. Chem. 50(9): 1279-1286; 1978 August.

[26] Shields, W. R.; Craig, D. N.; Dibeler, V. H. Absolute Isotopic Abundance Ratio and the Atomic Weight of Silver. J. Amer. Chem. Soc. 82: 5033-5036; 1960 October.
[27] Bower, V. E.; Davis, R. S.; Murphy, T. J.; Paulsen, P. J.; Gramlich, J. W.; Powell, L. J. A Redetermination of the Faraday Constant Due to a New Atornic Weight of Silver. J. Res. Nat. Bur. Stand. (U.S.). B7(1): 21-23, 1982 January-February.

[28] Cohen, E. R.; Taylor, B. N. The 1973 Least Squares Adjustment of the Fundamental Constants. J. Phys. Chem. Ref. Data 2(4): 663-734; 1973. 